\title{
Trace Element and Isotope Geochemistry of Siberian Kimberlites
}

Nowell, G. $\mathrm{M}^{1,2}$, Kempton, P.D ${ }^{2}$ and Pearson, D.G. ${ }^{1}$

1. Department of Geological Sciences, Durham University, South Road, Durham, DH1 3LE, UK

2. NERC Isotope Geosciences Laboratory, Kingsley Dunham Centre, Keyworth, NG12 5GG, UK

\section{Introduction}

As part of a larger study investigating the Hf-Nd isotope compositions of kimberlites and lamproites from South Africa, Australia, and North America (Nowell et al. 1998a, b), we have undertaken a geochemical survey of a small number of kimberlites from Siberia. The areas under investigation include the Malo-Botuobinsk field (Mir, Internationalaya) and the Daldyn-Alakit field (Udachnaya, Aikhal, Jubilee, Sytikanska and Zarnitsa); the Udachnaya sample is from the East pipe. Samples were collected from open pit workings where possible, or from dumps, and are mostly tuffisitic kimberlite breccias (TKB's) containing relatively abundant megacrysts of magnesianilmenite, chrome-pyrope and altered olivine. Inclusions of mega-crystalline dunites are also common in some samples. The freshest possible material was obtained, with areas of obvious nontronite alteration being avoided. Significant effort was expended in picking out as much of the xenolith and megacrystic material as possible during sample crushing.

\section{Geochemical Results}

Results of trace element and isotopic analysis are presented in Table 1 and Figures 13. In extended trace element diagrams (i.e. 'spider' plots) the Siberian kimberlites lie within the range of Group I kimberlites from South Africa, showing strong enrichment of the LREE as well as relative depletions in $\mathrm{Sr}$, Hf and $\mathrm{Zr}$ (Fig. 1). Two samples from the Aikhal pipe (A3 and A4) have virtually identical trace element patterns, except that A4 has significantly lower Pb contents than A3. Sample M3 has a slightly different pattern for the most incompatible LIL elements when compared with the other Siberian samples in that it lacks a strong Ba spike.

In a plot of ${ }^{87} \mathrm{Sr} /{ }^{86} \mathrm{Sr}$ vs. ${ }^{143} \mathrm{Nd} /{ }^{144} \mathrm{Nd}$ (Fig. 2) the

Siberian samples define a small cluster of points that lie just outside the field of Group I kimberlites from South Africa, having slightly higher ${ }^{87} \mathrm{Sr} /{ }^{86} \mathrm{Sr}$ at a given ${ }^{143} \mathrm{Nd} /{ }^{144} \mathrm{Nd}$. They are clearly distinct from Transitional and Group II kimberlites.

In contrast to their $\mathrm{Sr}-\mathrm{Nd}$ isotope systematics, $\mathrm{Pb}$ isotopes for the Siberian kimberlites show a very wide range. Three samples lie within the field of

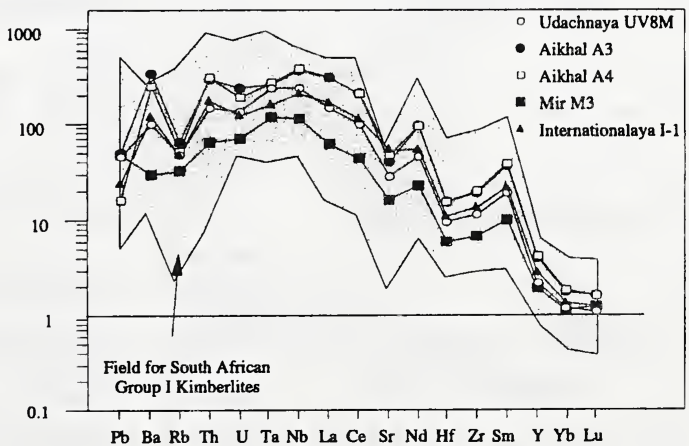

Figure 1. Spider plot of Siberian kimberlites compared with Group I kimberlites from South Africa. Concentrations are normalized to primitive mantle. 


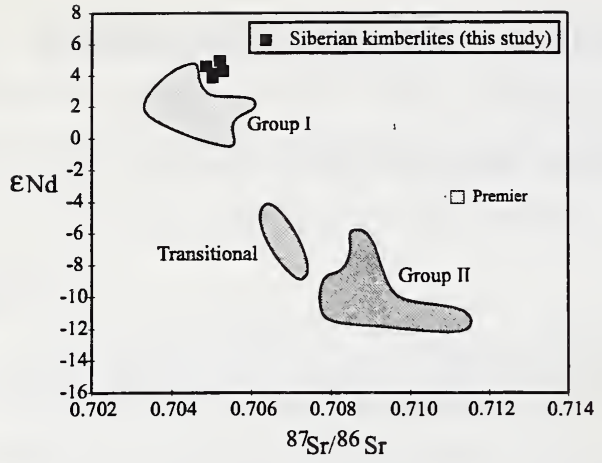

Figure 2. Plot of Sr vs. Nd isotopes comparing Siberian and South African kimberlites.
Group I kimberlites, but 2 extend to some of the highest ${ }^{206} \mathrm{~Pb} /{ }^{204} \mathrm{~Pb},{ }^{207} \mathrm{~Pb} /{ }^{204} \mathrm{~Pb}$ and ${ }^{208} \mathrm{~Pb} /{ }^{204} \mathrm{~Pb}$ values known for kimberlites. This is consistent with data for similar Siberian kimberlites (Fig. 3) described by Fefelov et al. (1991), who also observed that the higher ratios occur in the most carbonatized samples. Note that even though the two Aikhal samples analyzed in this study have nearly identical trace element compositions, they have vastly different $\mathrm{Pb}$ isotope compositions (Table 1 ), almost certainly acquired during or postemplacement.

Most of the Siberian kimberlites intruded evaporites and/or brines that are known to contain veins of calcite, sulfide and bitumen. Bitumen is known to have very radiogenic $\mathrm{Pb}$ isotope compositions because it typically contains disseminated uraninite (Parnell and Swainbank, 1990). Given the high concentrations of U (>1 wt\%) and extremely radiogenic $\mathrm{Pb}$ compositions of some bitumen $\left({ }^{206} \mathrm{~Pb} /{ }^{204} \mathrm{~Pb}>100\right)$, it is possible that the high ratios observed in the Siberian kimberlites are a function of contamination at relatively shallow levels in the crust during emplacement. This contamination appears not to have affected the $\mathrm{Sr}-\mathrm{Nd}$ isotope or trace element compositions of the rocks, presumably because the contaminant was relatively low in these other trace elements.
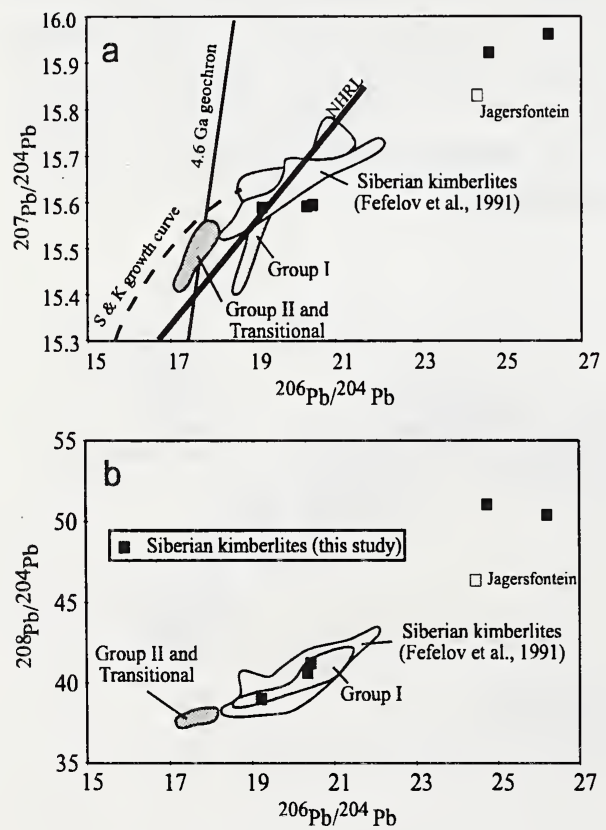

Figure 3. Plot of ${ }^{206} \mathrm{~Pb} /{ }^{204} \mathrm{~Pb}$ vs ${ }^{207} \mathrm{~Pb} /{ }^{204} \mathrm{~Pb}(\mathrm{a})$ and ${ }^{208} \mathrm{~Pb} /{ }^{204} \mathrm{~Pb}$ (b) comparing Siberian and South African kimberlites.

\section{Conclusions}

Siberian kimberlites are similar to Group I kimberlites from South Africa. Pb isotope systematics have probably been disturbed by shallow level contamination processes related to emplacement in the evaporite country rock.

\section{References}

Fefelov, N.N., Kostrovitskiy, S.I. and Zrudneva, N.V., 1991, Isotopic composition of lead and its use to date Siberian kimberlites: Doklady Akademii Nauk SSSr, v. 320, p. 1466-1469.

Nowell, G.M., Pearson, D.G., Kempton, P.D., Irving, A.J., and Turner, S., A Hf isotope study of lamproites: implications for their origins and relationship to kimberlites: this volume.

Nowell, G.M., Pearson, D.G., Kempton, P.D., Noble, S.R., and Smith, C.B., 1998b, The source regions/components of kimberlites: constraints from Hf-Nd isotope systematics: this volume.

Parnell, J. and Swainbank, I., 1990, Pb-Pb dating of hydrocarbon migration into a bitumen-bearing ore deposit, North Wales: Geology, v. 18, p. 10281030. 
Table 1: Trace element (ppm) and $\mathrm{Sr}-\mathrm{Nd}-\mathrm{Pb}$ isotope data for Siberian kimberlites

\begin{tabular}{|c|c|c|c|c|c|}
\hline Sample & UV8M & A3 & A4 & M3 & I-1 \\
\hline Sc & 12.33 & 16.19 & 16.82 & 10.15 & $\overline{11.77}$ \\
\hline $\mathrm{Ti}$ & 1.37 & 0.51 & 0.52 & 1.31 & 0.48 \\
\hline $\mathbf{V}$ & 105.70 & 71.69 & 66.42 & 92.93 & 60.16 \\
\hline $\mathrm{Cr}$ & 1437.52 & 1715.46 & 1139.73 & 870.24 & 1571.60 \\
\hline Mn & 0.12 & 0.10 & 0.10 & 0.11 & 0.12 \\
\hline Co & 76.75 & 65.18 & 53.61 & 94.54 & 56.37 \\
\hline $\mathrm{Ni}$ & 1140.30 & 1023.07 & 1055.12 & 1557.72 & 1486.39 \\
\hline $\mathrm{Cu}$ & 59.01 & 25.49 & 18.97 & 38.22 & 25.06 \\
\hline Zn & 33.44 & 43.21 & 8.79 & 44.10 & 29.53 \\
\hline Ga & 4.93 & 5.58 & 5.35 & 4.10 & 4.63 \\
\hline $\mathbf{R b}$ & 30.43 & 41.04 & 33.03 & 20.69 & 30.04 \\
\hline $\mathrm{Sr}$ & 593.01 & 848.77 & 993.73 & 339.24 & 1131.29 \\
\hline $\mathbf{Y}$ & 10.09 & 18.17 & 19.14 & 8.72 & 12.91 \\
\hline $\mathrm{Zr}$ & 126.58 & 216.16 & 226.27 & 76.75 & 153.29 \\
\hline $\mathbf{N b}$ & 170.07 & 265.20 & 275.54 & 80.82 & 151.57 \\
\hline Mo & 1.19 & 2.11 & 2.68 & 1.01 & 1.74 \\
\hline Cs & 0.72 & 0.31 & 0.27 & 0.99 & 0.39 \\
\hline $\mathbf{B a}$ & 695.44 & 2386.92 & 1772.93 & 207.00 & 842.58 \\
\hline Hf & 3.01 & 4.67 & 4.78 & 1.84 & 3.41 \\
\hline Ta & 9.73 & 10.57 & 11.09 & 4.81 & 6.73 \\
\hline $\mathbf{P b}$ & 8.47 & 9.38 & 2.92 & 8.91 & 4.48 \\
\hline Th & 12.39 & 25.40 & 26.22 & 5.54 & 15.03 \\
\hline $\mathbf{U}$ & 2.81 & 5.01 & 3.96 & 1.46 & 2.60 \\
\hline $\mathbf{L a}$ & 102.22 & 217.21 & 214.64 & 41.84 & 114.08 \\
\hline $\mathrm{Ce}$ & 174.50 & 375.52 & 374.21 & 78.47 & 200.69 \\
\hline Pr & 18.11 & 38.54 & 39.03 & 8.52 & 21.06 \\
\hline Nd & 62.19 & 129.64 & 131.63 & 30.34 & 73.21 \\
\hline Sm & 8.36 & 16.53 & 17.21 & 4.41 & 9.83 \\
\hline $\mathbf{E u}$ & 2.10 & 4.21 & 4.20 & 1.14 & 2.52 \\
\hline Gd & 4.22 & 7.68 & 8.35 & 2.61 & 5.04 \\
\hline $\mathbf{T b}$ & 0.59 & 1.14 & 1.19 & 0.38 & 0.73 \\
\hline Dy & 2.59 & 4.66 & 4.80 & 1.73 & 3.06 \\
\hline Ho & 0.39 & 0.67 & 0.70 & 0.29 & 0.46 \\
\hline $\mathbf{E r}$ & 0.84 & 1.34 & 1.39 & 0.68 & 0.92 \\
\hline $\mathbf{T m}$ & 0.11 & 0.17 & 0.17 & 0.10 & 0.12 \\
\hline $\mathbf{Y b}$ & 0.58 & 0.88 & 0.90 & 0.57 & 0.66 \\
\hline Lu & 0.08 & 0.12 & 0.12 & 0.09 & 0.09 \\
\hline${ }^{87} \mathrm{Sr} /{ }^{86} \mathrm{Sr}$ & 0.705222 & 0.705041 & 0.705358 & 0.705264 & 0.705394 \\
\hline${ }^{143} \mathrm{Nd} /{ }^{144} \mathrm{Nd}$ & 0.512576 & 0.512593 & 0.512615 & 0.512583 & 0.512588 \\
\hline${ }^{206} \mathrm{~Pb} /{ }^{204} \mathrm{~Pb}$ & 20.325 & 20.445 & 24.744 & 19.238 & 26.211 \\
\hline${ }^{207} \mathrm{~Pb} /{ }^{204} \mathrm{~Pb}$ & 15.592 & 15.594 & 15.922 & 15.590 & 15.961 \\
\hline${ }^{208} \mathrm{~Pb} /{ }^{204} \mathrm{~Pb}$ & 40.577 & 41.189 & 51.016 & 38.957 & 50.351 \\
\hline
\end{tabular}

Locations: UV8M - Udachnaya, A3 and A4 - Aikhal, M3 - Mir and I-1 - Internationalaya 